
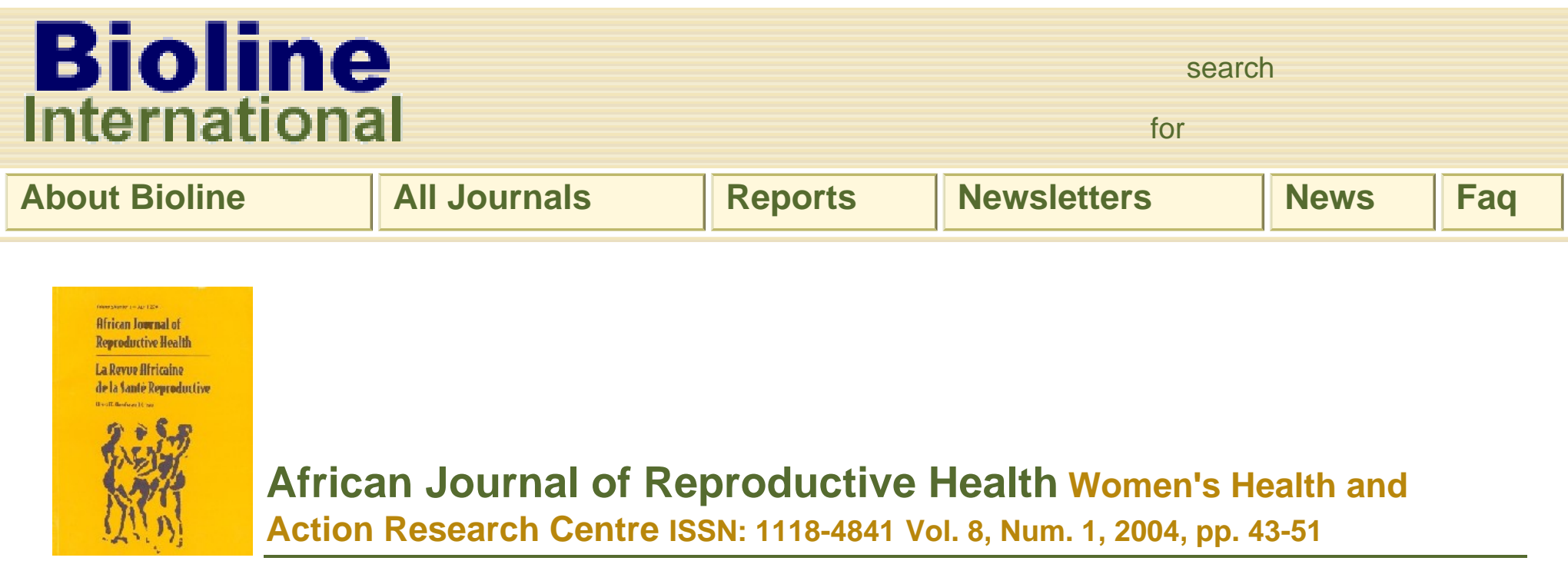

African Journal of Reproductive Health Women's Health and Action Research Centre ISSN: 1118-4841 Vol. 8, Num. 1, 2004, pp. 43-51

African Journal of Reproductive Health, Vol. 8, No. 1, April, 2004 pp. 43-51

\title{
The Power Dynamics Perpetuating Unsafe Abortion in Africa: A Feminist Perspective
}

Tamara Braam¹and Leila Hessini²

1Sonke Development Agency, 19th Floor, Ten Sixty Six Building, 35 Pritchard Street, Johannesburg, 2001 South Africa. Tel: 27-11-492-1927/8/9 (Office); 27-11-464-4580 (Residence); 27-82-324-5485 (Celluklar); Fax: 27-11-836-7945; E-mail: tamara@sonke.com 2Senior Policy Advisor, Ipas, 300 Market Street, Suite 200, Chapel Hill, North Carolina, USA. Tel: 1-919-942-3751 (Office); 1-919-960-6445 (Residence); E-mail: hessinil@ipas.org Correspondence: Ms. Leila Hessini, Senior Policy Advisor, Ipas, 300 Market Street, Suite 200, Chapel Hill, North Carolina, USA. Tel: 1-919-942-3751 (Office); 1-919-960-6445 (Residence); Email: hessinil@ipas.org

\section{Code Number: rh04008}

\section{Abstract}

Tens of thousands of African women die every year because societies and governments either ignore the issue of unsafe abortion or actively refuse to address it. This paper explores the issue of abortion from a feminist perspective, centrally arguing that finding appropriate strategies to reclaim women's power at an individual and social level is a central lever for developing effective strategies to increase women's access to safe abortion services. The paper emphasises the central role of patriarchy in shaping the ways power plays itself out in individual relationships, and at social, economic and political levels. The ideology of male superiority denies abortion as an important issue of status and frames the morality, legality and sociocultural attitudes towards abortion. Patriarchy sculpts unequal gender power relationships and takes power away from women in making decisions about their bodies. Other forms of power 
such as economic inequality, discourse and power within relationships are also explored. Recommended solutions to shifting the power dynamics around the issue include a combination of public health, rights-based, legal reform and social justice approaches. (Afr J Reprod Health 2004; 8[1]:43-51)

Key Words: Unsafe abortion, gender perspective, Africa, power, patriarchy

\section{Résumé}

\section{Pouvoir dynamique qui perpétue l'avortement à risque en Afrique: une perspective} féministe. Des dizaines des milliers des femmes africaines meurent chaque année parce que les sociétés et les gouvernements négligent la question de l'avortement à risque ou refusent carrément de l`aborder. Cet article étudie la question de l`avortement d’une perspective féministe, en avançant l’argument que la recherche des stratégies appropriées qui permettent de reclamer le pouvoir de la femme au niveau individuel et social constitue un lévier central pour l'élaboration des stratégies efficaces pour augmenter l'accès de la femme aux services de l’avortement sans risque. L’article met l’accent sur le rôle central du patriarcat en modélant les façons dont le pouvoir se mousse au niveau des rapports individuels: sociaux, économiques et politiques. L`idéologie de la supériorité masculine nie le fait que \’avortement est une question importante de statut et encadre la moralité, la légalité et les attitudes socio-culturelles envers \avortement. Le patriarcat sculpte des rapports de pouvior inégaùx et nie à la femme le pouvoir de prendre des décisions en matière concernant son corps. D`autres formes de pouvoir telles l'inégalité économique, le discours et le pouvoir au sein des rapports sont aussi explorés. Pour effectuer un changement dans la dynamique de pouvoir à l'égard du problème, nous préconisons, entre autres, une approche qui sera basée sur la santé publique, sur les droits, la réforme légale et la justice sociale. (Rev Afr Santé Reprod 2004; 8[1]:43-51)

\section{Introduction}

Unwanted pregnancies, unsafe abortion and resulting high levels of maternal mortality continue to cause irreparable harm to women in Africa, their families, communities and societies. Close to 100 African women die everyday, and many more are injured as a result of unsafe abortion. Indeed, unsafe abortion is a common experience in Africa. A WHO expert recently estimated that on average, each African woman will experience seven unsafe abortions in her reproductive lifetime. ${ }^{1}$ Young women, including adolescents, suffer disproportionately, with $40 \%$ of all unsafe abortions occurring in women between the ages of 15 and 24 years. Yet these premature deaths and injuries are easily preventable if safe effective technologies for contraception and pregnancy termination are available and utilised.

This paper is premised on the belief that African women, like their sisters elsewhere, have the right to life. It seeks to understand and deconstruct the underlying ideologies and power dynamics that undermine this right and that serve to sustain abortion as an illegal, unsafe and highly stigmatised procedure in African countries. Patriarchal ideologies and existing power structures shape policies concerning access to contraception, abortion and comprehensive sexuality education as well as the ability of women to make independent sexual and 
reproductive health choices. A focus on power dynamics helps to understand the continued marginalisation of abortion by drawing attention to those whose interests are at stake, those who benefit and those who suffer as a result. Women's bodies, as the personification of society reproducing itself, represent a critical arena for power struggles. Society has found ways to exert control over women's bodies through law, customs and traditions, and value systems. Criminalisation of abortion and consistent denial of women's right to bodily autonomy and decision-making is a means to control women's wombs, which are truly the forces of reproduction.

Although abortion is now highly stigmatised in the majority of African countries, social limitations on abortion have not always prevailed in the region. Anthropological and historical studies establish that in pre-colonial Africa, abortion was tolerated and not a hidden practice, although probably rare. The ancient Egyptians were some of the first to create abortion techniques. ${ }^{2}$ In some traditional African countries, abortion was used as a way of regulating population size and controlling those pregnancies that were considered undesirable such as those resulting from rape or involving young and unmarried women. ${ }^{3}$ Some ethnographic studies show that fetuses were not seen as having human attributes, for example, among the Akan peoples in Ghana. ${ }^{4}$ In general, the idea that "life begins at conception" is a relatively recent phenomenon in Africa. Abortion was practiced, but was relatively rare for several reasons, including the prestige associated with having as many children as possible; practical needs for children as a source of labour, wealth and care for the elderly; and the paramount importance attached to carrying on the family. Moreover, in most African societies, giving birth to children before or outside of marriage was not considered deeply shameful and, thus, abortion was not deemed necessary in those situations. 5

The colonial era introduced the concept of nation-states in Africa, complete with laws and policies imposed by the ruling powers that penalised and criminalised women who sought abortions as well as abortion providers. These laws reflected the thinking in Europe at the time. Contemporary abortion laws in Africa are mostly either direct or slight modifications of colonial laws; although in the past decade some countries have liberalised their laws, including Benin Republic, Burkina Faso, Chad, Guinea, Mali and South Africa. In the vast majority of cases, abortion laws were reinforced by family codes that emphasised women's reproductive role within the family and by traditional Western cultural beliefs governing marital relationships, pregnancy and childbearing. Despite their unsuitability, most of the colonial laws were maintained at independence by the new African governments, which were faced with major socio-economic issues and lacked the time, resources or political will to undertake full scale legal reform.

This paper analyses the different types of power that individually and together stand in the way of addressing unsafe abortion in Africa. We then propose strategies that can be used in order to shift power within the debate, reframe the discourse around abortion and empower women to make decisions about their own bodies and gain access to safe abortion care. As this presentation is our synthesis of research findings and thought from a wide range of sources, space does not permit acknowledgement of many of these. 
Bioline International Official Site (site up-dated regularly)

\section{Power Dynamics Perpetuating Unsafe abortion}

\section{The Power of Patriarchy}

Patriarchal power lies at the core of understanding abortion as a contested and political issue. Patriarchy is the systematic, structural, unjustified domination of women by men. It consists of those institutions, behaviours, ideologies, and belief systems that maintain, justify and legitimate male gender privilege and power. Men are viewed as the norm, and their life experiences and approaches are most often used as the basis on which to determine social needs, articulate policy requirements and assign resources.

The logical consequence of a male-defined and male-dominated world view is that experiences that are not directly informed by men's experiences, notably pregnancy, childbirth, abortion and violence against women, are not seen as priority areas. Critical areas that impact significantly on women's health and lives such as unsafe abortion cannot compete with traditional development priorities such as unemployment and poverty. While we are not arguing for a hierarchy of social needs, we believe that a feminisation of development issues is necessary, in which women's sexual and reproductive health and rights are seen as central to the sustainable human development agenda.

Simple biology means that it is only women who must deal with the realities of unwanted pregnancy including facing the potential dilemma of resorting to a life-threatening and unsafe abortion. By contrast, a male-dominated paradigm of development tells us in effect that (i) abortion is not an important social issue; (ii) abortion is immoral and wrong, most often based on interpretations of religious texts by male religious gatekeepers; and (iii) abortion is culturally problematic, as it challenges women's fundamental role and responsibility to bear children. Most often, abortion is simply neglected by policymakers because it affects women and because its significance and impact is not fully comprehended.

\section{The Political Power of Institutionalised Gender Inequality}

Gender inequality is pervasive in institutions that govern education, employment, religious practice and other critical areas of life. Political leadership is male-dominated and men's needs and experiences establish political agendas, the norms for policy decisions, and priorities for resource allocation. African responses to HIV/AIDS, for example, have failed to address adequately the realities of women's vulnerability to infection as a result of unsafe and unwanted sex.

Many political leaders have also deliberately ignored abortion because it is seen as a volatile issue that could compromise electoral support from key constituencies. In some countries, political trade-offs have been made with respective stakeholders in order to avoid the issue. In many parts of the continent, the power of the Catholic Church and its influence on politics has been cited as a major factor inhibiting political movement around abortion. ${ }^{6}$ There are some exceptions, however, that have happened when key political leaders have had direct experience of seeing the impact of unsafe abortion on women's lives and health and been willing to address 
Bioline International Official Site (site up-dated regularly)

this politically difficult issue. Another exception is the enabling political context - in which choice and human rights overall were emphasised and respected - that facilitated the enactment of liberal abortion legislation in South Africa in 1996.

\section{The Power of Laws and Legal Systems}

The legal system exerts significant power in framing values and giving legitimacy to notions of morality within a given society. Under current laws in many African countries, women are effectively criminalised for the reproductive choices they make, contributing to the trauma they already experience in seeking an unsafe abortion. The restricted legal status of induced abortion in many African countries reinforces the credibility of a number of societal messages that ultimately increase women's recourse to unsafe abortions: (i) it is a crime to terminate a pregnancy; (ii) it is immoral to terminate a pregnancy; (iii) access to safe abortion is not an integral part of compre-hensive reproductive health care service delivery; (iv) the right to abortion services is not a human right; and (iv) others can make decisions about women's bodies and their lives.

Overall, it is clear that the laws governing abortion are highly restrictive in Africa, with only three out of 54 countries allowing abortion to be performed on request during the first 12 weeks of pregnancy. The pace of reform has been slow and has not matched the changes that have taken place in the former colonial ruling countries.

\section{The Power of Religion and Culture}

Organised religion has played a powerful role in challenging the right of women to take control of their bodies and in molding the moral foundations for contemporary social constructions of "sex" and "sexuality." Through the images of the Virgin Mary and the female saints, Catholic teaching presents the idealised vision of a woman as chaste, virginal and loving. ${ }^{7}$ Protestant ideas about the family and relationships between husband and wife break with the traditional Catholic approach but are nevertheless full of contradictions. While the Catholic Church relies on priests to keep the "flock" from straying, some Protestant denominations in Africa invest fathers and husbands with spiritual authority. A necessary corollary is the inferiority of wives. In Islam, all human beings are equal in the eyes of Allah, but men and women are expected to fulfil specific roles such as head of the household or primary child-rearer. While a great deal of diversity has existed across Islamic thought ranging from full support for family planning and abortion, to limitations on women's reproductive autonomy, interpretations are increasingly being made that take such critical decisions away from women and place them in the hands of male interpreters and husbands.

Thus, religious ideology and practices have helped institutionalise the idea of male dominance in all decision-making including reproduction. This logic of male domination has in turn served to alienate women from their own bodies. "Alienation" from one's body suggests a separation from, a lack of engagement with, and powerlessness in taking responsibility for this critical determinant of one's own life, health and well-being. 
The religious cultural context in a country such as Malawi typifies the conservative Christian paradigm that serves to entrench women's inferiority and locate personal power and decisionmaking outside of the self. In a focus group conducted in a study on reproductive choice in Malawi, participants expressed the view that women's bodies belong to their husbands, to their families, to their extended families, to the society and, very importantly, to God. ${ }^{6}$ This conceptualisation serves to reinforce the idea of women not owning and taking control of their own bodies but, rather, viewing their bodies as vessels for men, for future children and for reproduction to serve social needs. If children are seen as God-given and women are merely the vessels to carry the life, they are seen as having no right to interfere with it.

The cultural value placed on birthing and childbearing in Africa is also a significant factor that shapes women's reproductive decisions and places a particularly painful onus on those women who opt to terminate a pregnancy. Women bear the burden of reconciling high social and familial expectations with the rough realities of surviving pregnancy, childbirth and childrearing in an economically harsh and challenging context. Even as abortion becomes more frequent, it is more often morally condemned in the context of religiously conservative and pronatalist cultural belief systems.

\section{The Power of Economic Inequality}

Poverty in Africa is a key determinant of unsafe abortion, affecting women's decision-making about unintended pregnancies as well as their access to safe care. Many women choose to terminate pregnancies because of economic hardship and inability to support a child. Economic pressures may even be responsible for the pregnancy in the first place, as studies show that girls in some African countries are increasingly being forced to sell their bodies to pay for basic necessities such as school books and food. Yet, in the absence of state welfare systems, women are expected to take responsibility for the care and well-being of their children. Additional children may thus contribute to the ongoing cycle of poverty, women's economic disempowerment and increased costs to health systems. Alternatively, if a woman chooses an unsafe abortion resulting in her death, her absence in the household can mean the loss of a crucial resource to her family and community. International research has shown that income earned by women is much more likely to improve the social status, health and standard of living of families than income earned by men. Safe motherhood literature reports that motherless children are three to ten times more likely to die within two years of their mothers' deaths than children who live with both parents. ${ }^{8}$

In countries where abortion is heavily restricted and provisions have not been made for safe abortion care - as is the case in most of Africa - health systems that are already overburdened must use significant resources to treat women suffering from abortion-related complications. In a number of countries, studies have found that a half or more of gynecological admissions to hospitals are women suffering from abortion complications. 9,10 Care of patients with complications of unsafe abortions consumes resources - beds, medication and personnel - that are critically needed for treatment of other diseases including HIV/AIDS. Often, if care is even available, the women who need it most lack transportation and money to access the care. Moreover, as previously noted, the women increasingly affected by unsafe abortion are 
disproportionately younger women; those least likely to be able to survive economically on their own. By contrast, in South Africa, where a liberal abortion law is in place, more low income women are gradually gaining access to care, and the health system has decreased expenditures for services to treat complications from unsafe abortion.

\section{Personal Power and Power in the Sphere of Relationships}

Societal constructions of womanhood play a central role in shaping individual women's sense of self and consequently their ability to exercise personal power in relation to their sexual and reproductive health. Motherhood, culturally viewed as a core aspect of womanhood, has had the following consequences: (i) childbearing accords women status and a degree of personal power; (ii) women are under considerable pressure to become mothers; (iii) motherhood is seen as a natural process over which women should not try and assert control; and (iv) abortion, as a deliberate intervention to stop the process of mothering, is therefore seen as the antithesis of women assuming their assigned role in life. By virtue of their biologically unique role in pregnancy, women potentially have significant personal power in relation to the issue of abortion. Yet this power is often eroded by these overt or internalised messages.

As women's choices and options have expanded in many areas of life, including education, work and others, their ability to exercise sexual and reproductive choices has not followed suit. Patriarchal, institutional, legal, economic, religious and cultural power structures play themselves out in private relationships and undermine women's confidence and ability to enjoy reproductive autonomy. The involvement of male partners contributes to the limitations women feel in this area.

Men have been socialised to make decisions, and many find self-expression through their ability to control financial resources and assert dominance. Women's need to remain attached to men due to legal, financial or cultural reasons often results in them giving up their human right to make decisions about whether and when to have children and how many to have. Women's lack of personal power to make decisions and choices about sex often threatens their lives and health because of HIV and other sexually transmitted infections and/or unwanted pregnancies. If a woman has an unintended pregnancy, her decision to resort to an unsafe abortion is heavily influenced by the response of her male partner to her pregnancy, the extent of her financial dependency on him, and her concerns about the survival of other children. Rather than putting a woman in a position of power, the practical ramifications of a pregnancy may increase her vulnerability and lack of power. In this context, unsafe abortion may become the means by which a woman takes back the power of decision-making in relation to her body despite the potential risks to her life and health.

\section{The Power of Discourse}

The discourse and language surrounding abortion is a significant factor in maintaining and entrenching a largely conservative approach to the issue. The discourse used by the anti-choice movement focuses on terms such as life, babies, families, all of which tend to put those who advocate for women's rights to control their bodies and access to safe abortion services morally 
on the defensive. By contrast, the discourse of abortion, death, blood and infertility conjures up highly unfavorable images in communities already facing death, disease and poverty as a result of a number of factors, including the high levels of HIV infection.

It is clear on closer examination that the core arguments of anti-abortion groups are not about protecting life per se but, rather, are reflections of a belief system that values women's lives primarily in relation to their ability to bring new life into the world. The fact that millions of women die globally from unsafe abortions, with Africa accounting for $40 \%$ of these deaths, appears to be of little consequence to these groups; what matters most is that the lives of fetuses, which are totally unable to survive outside of the womb, be maintained and protected.

The discourse of the anti-choice movement historically has played a significant role in defining the terms of debate. As we will discuss further, it is critical to find innovative ways to shift the power within the debate, reclaim the concept of life and re-conceptualise the issue of abortion in paradigms of sustainable human development, social justice, public health, human rights and self-determination.

The power of saying one thing but doing another also serves to reinforce an anti-choice message. Five years of implementing legal safe services in South Africa have highlighted the existence of a dual morality in relation to the issue of abortion, in which individuals who are vocally opposed to abortion actually choose pregnancy termination when an unwanted pregnancy affects them personally. ${ }^{11}$ This duality between actual behaviour and expressed attitudes may present an opportunity to shift thinking around the issue of abortion and needs to be explored creatively.

\section{Approaches to Shifting the Power Dynamics}

The previous section has provided an overview of the power structures that serve to sustain the illegal and taboo status of abortion across Africa. Women who are disadvantaged by poverty, geographical location, racism, age, economic status, violence and other forms of social marginalisation need support to take full control over their bodies. To move toward the goal of increasing women's access to safe abortion services, it is critical to confront the deep systemic issues of unequal gender power relations, inadequate and under-funded health systems, and lack of political will. The role of religious, cultural and patriarchal institutions as gatekeepers must also be examined and critiqued. Attitudes regarding women's sexuality and reproductive choice are constructed through ideology and given expression through discourse; we believe that they can also be challenged and deconstructed. The following section will highlight different approaches that have been used to shift the power relationships that affect women's access to safe abortion, drawing on legal, rights-based, public health and social justice frameworks.

\section{A Legal Reform Approach}

Advocacy efforts exist in a number of African countries to change the criminal nature of abortion laws, either by completely overturning or modifying current legislation. This approach has usually involved one or more of the following strategies: (i) clarifying and informing women and 
providers of existing legislation and ensuring that abortion services are available for all legal indications; (ii) expanding the indications for which abortion is legal; (iii) decriminalising existing codes that include punitive measures for women seeking and providers offering abortion services; and (iv) removing regulatory and medical barriers that impede women's access to services.

These approaches are necessary as women and health care providers are often not aware of the right to legal abortion in certain circumstances or of the availability of safe legal services for those conditions. Indeed, in every African country, abortion is allowed for certain indications. However, these laws are usually not enforced and services often do not exist to ensure their implementation. In addition, other barriers may limit women's access including who can provide abortion and where, spousal and parental consent, waiting periods and approval procedures, biased counselling, and the use of conscientious objection by providers to avoid performing abortions when no other providers are available.

\section{A Rights-Based Approach}

The vast majority of African countries have joined the international community and have agreed that all human beings are born free and equal in dignity and rights, and that these rights are unalienable and indivisible. In 1968 at a UN review of the Universal Declaration of Human Rights in Teheran, govern-ments agreed that parents have a basic right to determine freely and responsibly the number and spacing of their children.

The Convention on the Elimination of All Forms of Discrimination Against Women (CEDAW), which came into force in 1981 is the first international treaty in which member countries assume the legal duty to eliminate all forms of discrimination against women in the civil, political, economic, social and cultural areas including health care and family planning, pregnancy, childbirth and the postnatal period. The right to equality and non-discrimination means that a woman should not be subject to discrimination in any way simply because she is a woman. Based on CEDAW and other international human rights instruments, denying a woman access to abortion can be interpreted as a violation of her human rights.

\section{A Public Health Approach}

Unsafe abortion in Africa is a public health tragedy affecting tens of millions of African women alive today, many of them adolescents, with impacts extending to men, children, communities and entire health systems. African governments have joined in supporting the Millennium Development Goal of reducing maternal mortality. Preventing unsafe abortion is essential to achieve this goal. Preventive investments in making family planning and safe abortion information and services accessible can dramatically decrease the incidence and consequences of unsafe abortion as well as the high costs associated with managing abortion complications. Many root causes of unsafe abortion are the same as those underlying the HIV/AIDS pandemic. These include lack of access to comprehensive reproductive health information and services and women's lack of decision-making power related to sex and reproduction. Effectively addressing those root causes can have a positive impact on a range of related health and social 
problems. Ironically, while men often dominate in decisions about women's bodies, many educational interventions have targeted women. A strong public health approach should engage with men on issues relating to sexual and reproductive health.

\section{A Social Justice Approach}

A social justice framework requires a re-conceptuali-sation of abortion from an issue that is exclusively a woman's concern to one that is a concern for the society as a whole. Two issues of social justice should be examined: (1) the inequality that rich and poor women have to safe abortion regardless of legal availability; and (2) the impact of a woman's death or long-term illness from unsafe abortion on her family, her work and her community at large. Viewed from these perspectives, unsafe abortion becomes a societal problem in which women are denied the basic human right to make choices and decisions about their bodies and to have access to the means to do so. Approached in a social justice framework, unsafe abortion would become a concern of men, families, communities, statesmen and policymakers, health providers, and rights activists.

Linkages should also be made between the basic right of national self-determination, as expressed in many anti-colonial struggles, and the right of all individuals to self-determination in relation to their bodies. The parallels between the impact of colonialism on dispossessed peoples and the impact of male-dominated decision-making on women's bodies need to be explored and made in ways that do not alienate but rather build support and understanding for women's access to safe abortion services as part of comprehensive reproductive health care.

\section{Toward Effective Strategies to Increase Women's Access to Safe Abortion}

Drawing on the above approaches and the exploration of power, it is clear that a women's rights and feminist agenda is needed. Women must reclaim their power at a personal and relationship level and link their individual power with each other, building strong social movements around the issue of choice in a broad sense of the term, ranging from the choice about when and with whom to engage in sexual relationships, to choice in use of high quality affordable contraception and the choice to bear and raise children. The decision to terminate an unwanted pregnancy is only one issue in a broad range of issues that most directly affect women. Women's control of their bodies and their need to understand, enjoy and look after their own bodies, is at the very heart of women's empowerment. Such control potentially gives women significant social power particularly as their bodies represent the forces of reproduction, a power that society has historically sought to take away through law, cultural norms, violence and exclusion. Instead, society must assume responsibility for the processes associated with human and social reproduction and create an enabling environment for sexual and reproductive choice.

To facilitate women's ability to control their own bodies, interventions need to take place at individual, social, political, economic, religious and cultural levels. Specific strategies to begin to shift the power dynamics include: 
rights, socio-economic justice and sustainable human development. This approach is necessary in order to destigmatise the abortion debate, build cross-sectoral support with seasoned civil society advocates, and ensure that male voices supporting choice and rights are heard across Africa.

- Reclaiming the moral high ground, with emotive language, images and discourse focused on the life-saving nature of access to safe abortion and its grounding in human rights principles.

- Making linkages to other critical issues such as the HIV/AIDS pandemic and children's rights. The HIV/AIDS pandemic has moved from the previously private realm of sexual relations and sexual behaviour to the political centre stage; unsafe sex is the common root of both HIV infection and unwanted pregnancy. In the area of children's health and rights, it is important to link the health and well-being of children with that of women and emphasise that the right of every child to be a wanted child is linked to a woman's right to self-determination.

- Mainstreaming the issue of abortion as part of overall advocacy campaigns focused on such critical issues as poverty eradication, HIV/AIDS prevention, violence against women and women's rights more broadly, engaging men as well as women.

Recent examples of abortion-related activism in Africa suggest that openness to engage around the issue may be greater than many expected. Advocates for safe abortion have often been hesitant about putting abortion on the public agenda. In an attempt to be strategic, around an issue that has been shrouded in religious and cultural sensitivity, advocates at times have arguably made the mistake of being apologetic in their approaches. This approach serves abortion opponents well, as it reinforces the secrecy and silence that they have created around the abortion question. In many instances, advocacy has not taken place at all because relevant stakeholders have not met even to have a conversation about the issue. Providing a forum where ideas and information can be exchanged is a critical step towards breaking the silence and creating the building blocks of concrete strategies to address the issue. Notable recent examples of such forums are (i) the first ever region-wide consultation explicitly on unsafe abortion in Addis Ababa in March 2003, which brought together a wide range of critical stakeholders including government ministers; and (ii) the tabling of the Protocol to the African Charter on Human and People's Rights on the Rights of Women in Africa at the African Union meeting in July 2003 in Maputo. The Charter explicitly states that:

State Parties shall take all appropriate measures to protect the reproductive rights of women by authorising medical abortion in cases of sexual assault, rape, incest and where the continued pregnancy endangers the mental and physical health of the mother or the life of the mother or the foetus.(Article 14, Section 2)

\section{Conclusion}

Ensuring women's access to safe abortion is a political challenge that requires building an understanding of the issue at all levels of society, linking it to other critical issues and framing it in ways that encourage a holistic and integrated approach. Abortion must be demystified, 
simplified and embraced as contributing to an African continent in which all human beings, men and women, are able to fully exercise their human rights. Ultimately, it is necessary to shift from penalising and even criminalising women for abortions to recognising abortion as an extremely common experience, a positive social need and the right of all women of childbearing age. The tactics and strategies used to facilitate such a shift have to lay claim deliberately to the language of those historically challenging access to safe services. No apology should be necessary for the need to save women's lives. Instead, asserting the value of women's lives is an integral part of rebuilding a continent around the principle of self-determination and self-emancipation. Advocating for access to safe abortion services is part of the rebirth of an Africa in which all women, all children, all men and all communities can determine their own destinies.

\section{References}

1. Shah I and $E$ Åhman. Regional variation in age patterns of unsafe abortion. Reprod Health Matters (In press 2004).

2. Devereux G. A Study of Abortion in Primitive Societies. New York: International Universities Press, 1976.

3. Lema V and Njau P. Abortion in Kenya: Traditional Approach to Unwanted Pregnancy. Nairobi: The Center for the Study of Adolescence, 1990.

4. Bleek W. Avoiding shame: the ethical context of abortion in Ghana. Anthropol Quart 1980; 54(4).

5. Eser A and Hans-Georg Koch (Eds.). Schwanger-schaftsabbruch im Internationalen Vergleich. Baden-Baden: Nomos Verlagsgesellschaft, 1988.

6. Braam T and Dangor Z. SADC research project: giving sexual reproductive choice a regional voice. Reproductive Rights Alliance, 2002.

7. Hamilton R. The Liberation of Women: A Study of Patriarchy and Capitalism. London: George Allen and Unwin, 1978.

8. Safe Motherhood Initiative. Maternal Health. A Vital Social and Economic Investment. http://www. safemotherhood.org/facts and figures/good maternal health.htm .

9. Archibong El. Illegal induced abortion - a continuing problem in Nigeria. Int J Gynecol Obstets 1991; 34: 261-265

10. Konje J, Obisean KA and Ladipo O. Health and economic consequences of septic induced abortion. Int J Gynecol Obstet 1992; 37: 193-197.

11. Reproductive Rights Alliance. Five-year review of the implementation of the Choice on Termination of Pregnancy Act, 92 of 1996. Barometer 2002; 7(May).

12. Arcana J. Every Mother's Son: The Role of Mothers in Making of Men. London: The Women's Press Ltd, 1983.

13. Coontz S and Henderson P. Women's Work, Men's Property: The Origins of Gender and Class. London: Thetford Press, 1986.

14. Farmer P, Connors M and Simmons J. Women Poverty and AIDS: Sex, Drugs and Structural Violence. Cambridge: Common Courage Press, 1996. 
15. Henshaw SK, Singh S and Haas T. The incidence of abortion worldwide. Inter Fam Plann Persp 1999; 25(Suppl.).

16. Kinoti SN, Gaffkin L, Benson J and Nicholson LA. Monograph on Complications of Unsafe Abortion in Africa. Commonwealth Regional Health Secretariat for East, Central and Southern Africa, 1995.

17. Klugman B and Budlender D. Advocating for Abortion Access: Eleven Country Studies. Johannesburg: The Women's Health Project, 2001.

18. Konje J, Obisean KA and Ladipo O. Health and economic consequences of septic induced abortion. Int J Gynecol Obstet 1992; 37: 193-197.

19. . Meena R. Gender in Southern Africa: Conceptual and Theoretical Issues. Harare: Jongwe Printers, 1992.

20. . Morrel R. Changing Men in Southern Africa. Pietermaritzburg: University of Natal Press, 2001.

21. Palmer G. The Politics of Breastfeeding. London: Pandora Press, 1988.

22. The Alan Guttmacher Institute. Sharing Responsibility: Women, Society and Abortion Worldwide. New York: The Alan Guttmacher Institute, 1999.

23. Warren KJ. Ecological Feminism: Environmental Philosophies. London: Routledge, 1994

(C) Women's Health and Action Research Centre 2004 